July 2007

\title{
Tackling Copyright in the Digital Age: An Initiative of the University of Connecticut Libraries
}

Barbara Oakley

Betsy Pittman

Tracey E. Rudnick

University of Connecticut, traceyrudnick@gmail.com

Follow this and additional works at: https://opencommons.uconn.edu/libr_pubs

\section{Recommended Citation}

Oakley, Barbara; Pittman, Betsy; and Rudnick, Tracey E., "Tackling Copyright in the Digital Age: An Initiative of the University of Connecticut Libraries" (2007). Published Works. 8.

https://opencommons.uconn.edu/libr_pubs/8 
Author Bio: Barbara Oakley, MA, MLIS, Director of Library Access Services, University of Connecticut Libraries, 369 Fairfield Way, Unit 2005C, Storrs, CT 06269-2005, Barbara.Oakley@uconn.edu; Betsy Pittman, MA, MLS, University Archivist, Thomas J. Dodd Research Center, 405 Babbidge Road, Storrs, CT 06269-1205, Betsy.Pittman@uconn.edu; Tracey Rudnick, MM, MLIS, Music Librarian, Music \& Dramatic Arts Library, 1295 Storrs Road, UNIT 1153, Storrs, CT 06269-1153, Tracey.Rudnick@uconn.edu.

\title{
Tackling Copyright in the Digital Age: An Initiative of the University of Connecticut Libraries
}

\author{
Barbara Oakley, Betsy Pittman, and Tracey Rudnick
}

\begin{abstract}
From 2005 to 2007, the University of Connecticut Libraries Copyright Project Team engaged in a wide range of activities to fulfill its charge and to raise awareness of copyright issues in the library and across the university. This article highlights some of the primary activities and tools used by the team to involve stakeholders, to provide educational opportunities, and to stay current on copyright issues in higher education. Among other activities, the team developed a new copyright web site for use by library staff and the broader university community.
\end{abstract}

Keywords: copyright, fair use, intellectual property, task teams, policy development, web-site development, institutional repository, scholarly communications, author agreements, higher education.

Has your university been visited by the RIAA recently? Are you reconsidering your e-reserves because of what you hear in the news? Are patrons asking library staff for advice about copyright issues related to their teaching, research, and learning? The University of Connecticut Libraries faced exactly these concerns in the spring of 2005. Inspired by an influx of questions-many associated with new electronic services at the university-and the rapidly changing legal landscape, the library decided to tackle the issue of copyright head on.

\section{BACKGROUND}

The inevitable questions arose right away. Does the university not have a policy? Why should the library get involved?

Before 2005, the issue of copyright within the university community, including the Libraries, was handled on an ad hoc basis, addressed by individual areas and divisions as issues arose, independent of other areas and services. A few university policies did address some overarching issues: ownership of works created at the university; the illegal distribution of software or other material via university computing and networking systems; and procedures for handling DMCA-infringement complaints. However, these documents were general in nature and vague in approach; readers would not find specifics to answer day-to-day questions, nor would they find policies related to the use of copyrighted information in the course of teaching, learning, research, and publishing. The university does have a Center for Science and Technology Commercialization to handle trademark and patent concerns for the university, but similarly it is not in their purview to deal with general intellectual property or copyright issues.

U.S. copyright law, especially section 110(2) (the TEACH Act), now requires universities to 
establish institution-wide policies and identify contact persons in order to take advantage of privileges afforded to academic uses, especially in the context of distance education. The university had identified a person assigned to handle reported abuses. University staff could also consult the Office of the Attorney General on copyright issues that arose within the context of their public employment. Neither of these offices was equipped to handle the potential volume of questions that might result if everyday issues were directed to them, and the university did not have any other clearly identified office or individual to handle routine copyright questions from the university community.

Members of the university community often turned to library staff for their copyright questions, and library staff frequently faced similar questions in their own day-to-day work. Due to the nature of their responsibilities, librarians were in a position to know and keep up with fundamental copyright principles, though no one on the library staff was qualified or claimed to offer legal advice. In addition, the number and variability of questions increased as electronic access to copyrighted material grew. This ultimately led to a wide range of understandings among staff and users about the law as expertise and context varied.

Thus, the minimal direction at the university level, the changing nature of copyright enforcement, and increasing questions and complexities faced by the library staff prompted the Libraries to launch a copyright initiative as a strategic priority for two consecutive fiscal years, 2005-2007. This objective was just one component of the Libraries' strategic plan, in which the library was called to "provide leadership and expertise for the university community as scholarly communication systems are transformed." Among other activities, the library set a goal for itself to "articulate evolving library copyright issues for the university community."1

In July 2005, the Copyright Project Team, made up of three librarians, was charged to develop policies and guidelines on copyright and related legal issues for the Libraries to follow; to develop guidelines for staff, patrons and researchers, as appropriate; to recommend further actions to introduce these issues to the larger university community; and to maintain current and evolving knowledge of this area within the libraries. The project team was not responsible for enforcing copyright compliance at the university or providing legal advice to staff or users. Nevertheless, the activities of the project team have permitted the Libraries to serve as a leader for the university and regional professional communities.

Over the two years of its existence, the Copyright Project Team engaged in a wide range of activities to fulfill its charge and to raise awareness of copyright issues in the library and across the university. This article highlights some of the primary activities and tools used by the team to involve stakeholders, to provide educational opportunities, and to stay current on copyright issues in higher education. Many more activities and events than can be detailed here were part of the process. For a timeline of major milestones, see Table 1. 
Table 1. Timeline of Events and Important Milestones

\begin{tabular}{|c|c|c|c|}
\hline & Administrative & Policy \& Web-site Development & Staff/Public Events \\
\hline Spring 2005 & Team formed & & Webcast on orphan works \\
\hline Summer 2005 & $\begin{array}{l}\text { Scan of internal and external } \\
\text { copyright environment }\end{array}$ & & Webcast on applying fair use \\
\hline $\begin{array}{l}\text { Fall } \\
2005\end{array}$ & $\begin{array}{l}\text { Staff survey to assess knowledge } \\
\text { and identify expertise/needs }\end{array}$ & $\begin{array}{l}\text { Assemble outline of web-site } \\
\text { topics and potential policies }\end{array}$ & \\
\hline Spring 2006 & $\begin{array}{l}\text { Identify and secure approval for use } \\
\text { of outside legal counsel }\end{array}$ & $\begin{array}{l}\text { Develop web-site framework and } \\
\text { prototype }\end{array}$ & $\begin{array}{l}\text { Copyright forum and web-site } \\
\text { preview }\end{array}$ \\
\hline Summer 2006 & $\begin{array}{l}\text { Consultation with administrators } \\
\text { across university* }\end{array}$ & $\begin{array}{l}\text { Web-site content development; }{ }^{*} \\
\text { secure content permissions }\end{array}$ & \\
\hline $\begin{array}{l}\text { Fall } \\
2006\end{array}$ & Consultation with library units* & $\begin{array}{l}\text { Draft library policies; reviewed by } \\
\text { legal counsel* }^{*}\end{array}$ & \\
\hline October 2006 & $\begin{array}{l}\text { Web-site and progress report for } \\
\text { library leadership }\end{array}$ & Informal web-site release* & $\begin{array}{l}\text { Web-site introductory sessions } \\
\text { for library staff }\end{array}$ \\
\hline November 2006 & & & Article in library newsletter \\
\hline December 2006 & $\begin{array}{l}\text { Presentation to library's faculty } \\
\text { advisory committee }\end{array}$ & & $\begin{array}{l}\text { Boston Library Consortium } \\
\text { copyright forum }\end{array}$ \\
\hline January 2007 & $\begin{array}{l}\text { Submit charge for a university-wide } \\
\text { copyright committee to the } \\
\text { President's Office }\end{array}$ & Formal web-site release ${ }^{\star}$ & Article in university newspaper \\
\hline February 2007 & $\begin{array}{l}\text { General library policy statement } \\
\text { approved by library leadership }\end{array}$ & & \\
\hline March 2007 & $\begin{array}{l}\text { Link to copyright web site added to } \\
\text { university's policies web page }\end{array}$ & & $\begin{array}{l}\text { Authors' rights brochure (with } \\
\text { Scholarly Communications } \\
\text { Team) }\end{array}$ \\
\hline $\begin{array}{l}\text { May } \\
2007\end{array}$ & $\begin{array}{l}\text { Team's final report to library } \\
\text { leadership }\end{array}$ & & \\
\hline Future & $\begin{array}{l}\text { Library participation on university } \\
\text { committee on copyright? }\end{array}$ & Continued web-site development & $\begin{array}{l}\text { Additional outreach and } \\
\text { resources for library staff and } \\
\text { university community }\end{array}$ \\
\hline
\end{tabular}

\section{GETTING STARTED}

Where would the team begin? Was there not good information about copyright on the web already? Why reinvent the wheel?

With these and many other questions looming, the team's first project was to get a feel for the copyright landscape. Each team member had some knowledge of copyright issues because their respective job responsibilities required it, but none felt they had a truly comprehensive view. The team began by performing an environmental scan of copyright web sites and policy statements across higher education. After viewing dozens of sites, the team identified several that were useful or even outstanding in one or more aspects. Each had some particularly relevant content or effective approach to site organization. While no one site addressed all of the needs the team had identified, each helped formulate the team's early thinking and provided content and layout ideas for subsequent web-site design.

The team also performed an internal environmental scan. The team inquired library-wide about known policies or guidelines put out by the library, in addition to issues, questions and concerns, and 
staff knowledge and self-identified expertise. Armed with this information, the team developed a survey for staff. See Table 2 for sample survey questions. Conducted in December 2005, the survey assessed the general level of library staff knowledge and awareness of copyright, fair use, and the relationship of both to library materials. The survey also asked library staff to prioritize library services and types of questions that would most benefit from copyright policies or guidelines. The survey not only helped the team assess the state of knowledge and staff concerns, it also served as a vehicle for inviting library staff participation. It was clearly understood that everyone had a stake in the development process. Later meetings with individuals and library teams focused on library services such as interlibrary loan and reserve, and related library activities such as scholarly communications, a new institutional repository, and digital collections. The substantial level of staff input from the beginning and throughout the project fostered a general spirit of "buy in" when the team rolled out a new copyright web site.

Table 2. Sample Survey Questions

\begin{tabular}{|} 
Each question was offered as true/false. \\
$\begin{array}{c}\text { The library should seek permission to use any copyrighted materials for course reserve. } \\
\text { An author must register a work with the Copyright Office to receive copyright protection. } \\
\text { Copying at the university is fair use because it's for educational purposes. } \\
\text { To take advantage of the benefits of the TEACH Act, an academic institution must have } \\
\text { an institution-wide copyright policy. } \\
\text { Fair use allows libraries to circumvent encryption technologies in digital formats for the } \\
\text { purposes of research and scholarship. } \\
\text { Contractual arrangements and licensing agreements take precedence over fair use. } \\
\text { The survey was distributed to all library staff in December 2005. Forty-seven } \\
\text { percent of the staff completed the survey. }\end{array}$ \\
\hline
\end{tabular}

\section{PEOPLE TO HAVE ONBOARD}

It was not enough to have buy in from just the library staff. Copyright is an important ongoing issue for the university, so it is valuable to have the endorsement and support from offices and individuals who can help advance the agenda and knowledge of all members of the university community. The Libraries' Copyright Project Team sought out individuals and groups within the university who had a stake in the presentation and dissemination of knowledge of copyright and intellectual property issues as part of their responsibilities. The team built relationships with these stakeholders to further its work and to raise the profile of copyright issues within the university community. In the process, the team sought the approval of the university for its efforts, and sought the university administration's engagement as a central, authoritative voice in disseminating information and policies.

As counsel for the university, the state's attorney general on campus was a key representative from whom the team sought information and endorsement of its work. The attorney general's office provided the team with the perspective of the state with regard to the work of the university and all of its units, including the library. Members of the office worked with the team to provide overarching parameters for the team's work, to formulate general statements, and to approve specific language of key policies. The team consulted with members of the attorney general's office regularly throughout 
the process of developing the copyright web site to ensure that interested university offices were not working at cross purposes and that the library was not overstepping its bounds.

The university's compliance officer played a similar role in guiding the work of the team in accord with university policies. Members of that office were especially effective in disseminating information to the entire university community as a part of the ethical conduct training they provide. Moreover, it was at the suggestion of the compliance officer that the library's copyright web site was added to the University's ePolicies web site (http://policy.uconn.edu/pages/main.cfm).

For detailed legal advice and oversight of the team's policy development, the Libraries obtained outside legal counsel, with the approval and endorsement of the attorney general's office. This legal advisor was essential in helping the team create clear, understandable and legally supportable guidelines and policies that reflected the requirements of the local environment and respond to the needs of the local community.

The Libraries have ongoing relationships with university curriculum support divisions that assist faculty in creating new courses and provide technical assistance with enterprise tools like course management software. In the course of their work, curriculum support specialists encounter questions from faculty about copyright and what materials can or cannot be used for instruction. The copyright team continues to capitalize on these relationships to share information and to help develop policies and guidelines for campus users that reflect their experience and needs while working within copyright law.

The university has a robust program for technology commercialization, turning university research into marketable products through patents and licensing. The primary concern of this office is necessarily related to new intellectual property developments and, as such, comes from a very different perspective than the team encounters when members of the community want to use the intellectual property of others; this had implications for the team's work on the web site. Work with these patent experts reinforced for the team the importance of balancing the rights of creators and those of users. Regular contact with this office keeps these issues close in the team's thoughts as the team continues to develop resources and teach users on campus about appropriate uses of copyrighted information.

\section{FORUMS}

Each spring, the University Libraries sponsor an open forum on timely and forward-looking topics of interest to libraries and the academic community. Some examples of recent forum topics include the future of libraries, institutional repositories, universal web-site usability, and mass digitization projects.

In April 2006, the Libraries' forum was on the topic “Whose Rights \& Who’s Right: Copyright in the Digital Age” (http://www.lib.uconn.edu/copyright/whoseRights_Oakley.html). Speaker Robert Oakley, Law Librarian and Professor of Law at Georgetown University and Washington Affairs Representative for the American Association of Law Libraries, gave attendees a brief history of U.S. copyright law, highlighting some of the landmark cases that have molded the copyright landscape of today. Using examples provided by the audience, Professor Oakley showed how current practice and issues are being addressed in public-policy arenas and how academics and librarians can play a part in changing the course of copyright legislation.

The forum was widely attended by members of the UConn community and beyond, from all aspects of academia. Because the forum was so successful, the University Libraries arranged to have the talk repeated for the Boston Library Consortium at the Boston Public Library in December 2006.

Key factors in the success of the forum include the timeliness of the topic, widespread and attention- 
getting advertising, the knowledge and reputation of the speaker and the relevance of the topic to the work of academia.

\section{WEB-SITE DEVELOPMENT-LOGISTICS}

Creating a web site with copyright policy information was central to the team's activities. What would be the focus of the web site: internal policies for library staff to follow; information for the library's users; or information for the broader university community? Would the library have sufficient resources to create content? Who would maintain the site? Would the university be interested in contributing content or in adopting the web site for use on a broader scale?

The team decided to create a web site for use by the entire university community (http://www.lib.uconn.edu/copyright/), but recognized that some topics fell well beyond the library's purview. As such, the primary focus was on general copyright information and library services, with the understanding that the library could reach out to other service units and academic departments at the university at a later date. The team envisioned a modular web site that would be flexible enough to allow the addition of pages and cross-links that would accommodate new services, keep up with rapid changes in the copyright environment, and address a variety of user needs.

Using information from the environmental scan and the library staff survey, the team created a detailed outline of potential topics, noting places where outside input would eventually be needed. The outline was amended and approved by the university's counsel. Sketches for potential web-site organization began at the same time. These combined activities helped the team organize content, identify and prioritize issues, and map relationships between concepts.

Armed with the outline and sketches, the team worked with a library applications developer to create a template for the site's general appearance and navigation. Figure 1 shows a sample of the basic template. Over the next several weeks, one team member and the applications developer established site-wide templates, cascading style sheets, timesaving code-entry procedures, and documentation that would facilitate site-wide changes and ensure consistency. They also negotiated details related to the underlying organization and management of files, and fine tuned script-based navigation features such as the search box and drop-down menus. 
Figure 1. Image of a Sample Page Template

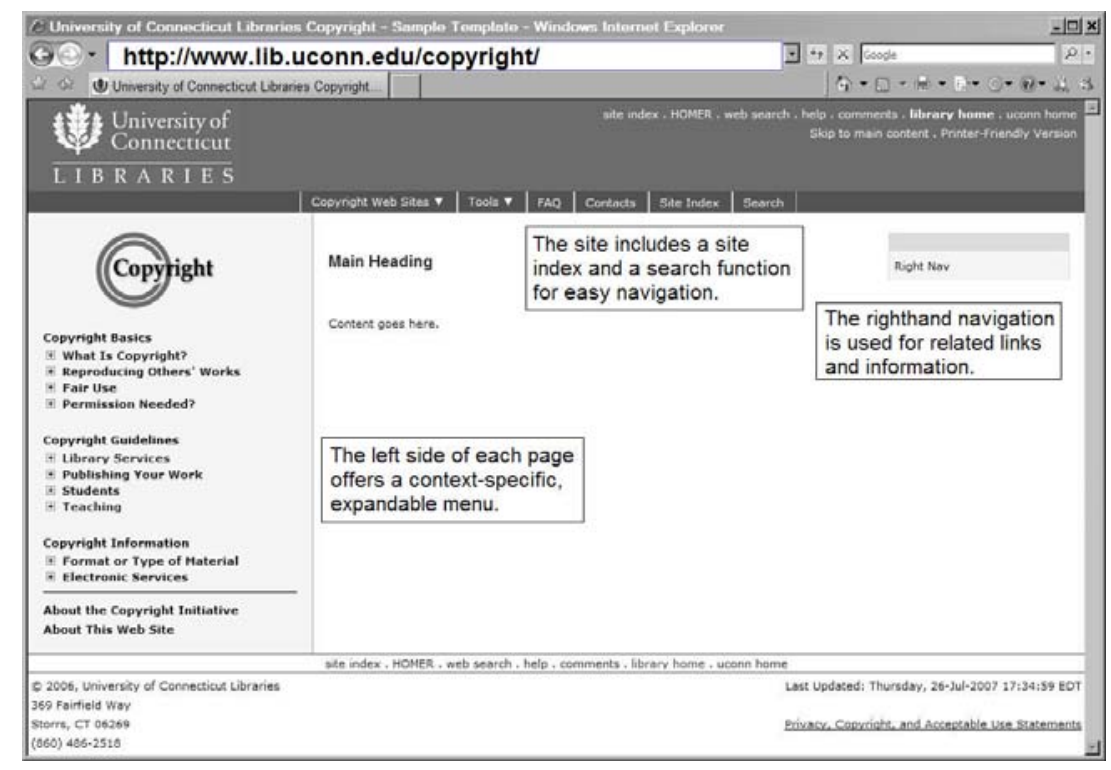

As another timesaver, the team contacted several institutions and requested permission to adapt information, presentation, or structure of their copyright web sites for the University of Connecticut Libraries' site. In this way, the team could avoid starting from scratch. Over time, it was explained, editing to reflect local practices and policies, as well as legal counsel's input, would eliminate overt similarities or outright lifting. Several institutions kindly gave their permission to use elements of their sites. ${ }^{2}$ Today's resulting content is a combination of original and researched content, preexisting university library policies, and content originally created at other sites.

During its development, the site resided in a test directory. Library staff and interested parties had access to the URL and were welcome to comment at any time, but were asked not to distribute the URL or use it in public settings. In October 2006, the team moved the site into its public directory for a "soft" rollout. The team held a series of open meetings to introduce the web site to library staff. Staff members were then asked to use it in day-to-day transactions, share the URL as appropriate, and send further feedback about real-life experiences using the site. The formal release occurred in January 2007, when the site was the focus of an article in the campus newspaper and the URL was distributed on brochures.

The web site serves a variety of important functions for the library and university. Most obviously, it is a central location where users from across the university (and beyond) can get useful and authoritative information about copyright that will answer many basic questions that arise in their day-to-day work. Beyond this, it provides a level of comfort and security to library staff to know that they can refer users to the site or rely on it themselves when assisting users with copyright questions in their work. Finally, involving staff and stakeholders in the development process allowed the team to address concerns and capitalize on expertise already available in the university. Because they were involved in the development, library staff members are also more likely to trust the information, to think of the resource in their day-to-day work, and to disseminate it further. 


\section{WEB-SITE DEVELOPMENT-WORKING WITH LIBRARY STAFF}

One of the first services the team addressed was course reserve. This involved staff from several service units at various UConn libraries. The main library's reserve unit already had a copyright policy that other service units followed to some degree or another, but the policy had not been substantively renewed or updated in several years. Reserve handles copyright issues on a daily basis, gets frequent questions from faculty, and must regularly explain how U.S. copyright law relates to reserve activities. Also, the proliferation of electronic resources used for reserve had raised new questions. The team undertook a complete overhaul of the policy statement, assembling relevant readings and sample policies from other institutions. Reserve staff brought their daily experience to the process and provided invaluable perspective and recommendations. The end product was a more comprehensive and up-to-date policy that better reflected the staff's work experience and answered many faculty questions - such as what could be placed on reserve, how to expedite service, and how the library defines ownership of material placed on reserve- thus freeing staff from this oft-repeated task. Figure 2 shows a screenshot of the Course Reserve Copyright Policy page.

Figure 2. Image of the Course Reserve Copyright Policy

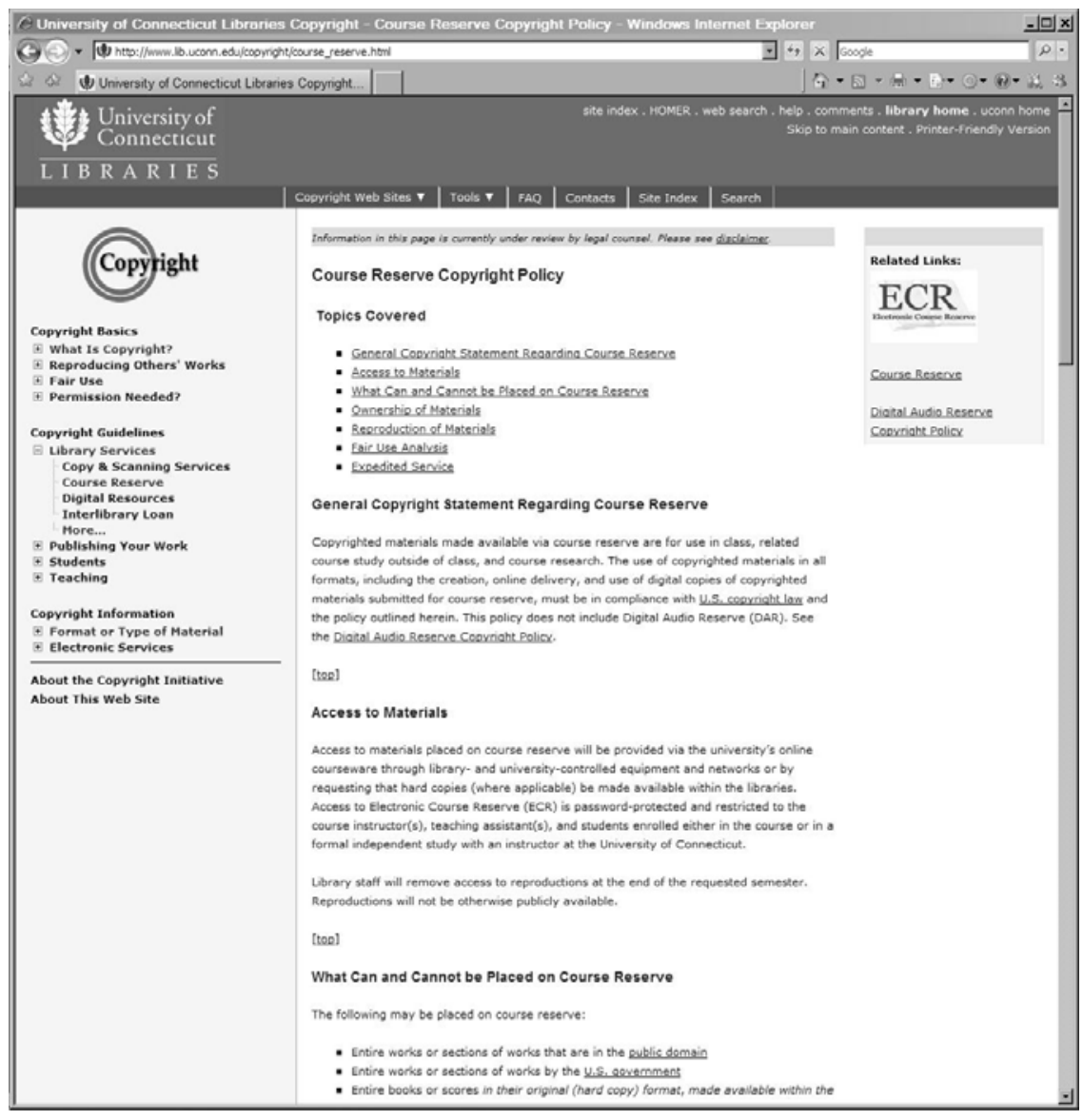

Document Delivery/Interlibrary Loan (DD/ILL) statements were considerably easier to craft. The guidelines for ILL are more straightforward and less flexible, and therefore less ambiguous. Also, copyright management of DD/ILL requests is handled almost exclusively behind the scenes by 
DD/ILL staff. The copyright team found that while the guidelines themselves were clear, they were not widely known outside of the DD/ILL office. They needed to be articulated so that DD/ILL users and staff members outside the DD/ILL office would know how copyright requirements might affect their work. It was easy enough to relate the roles and responsibilities in a concise statement that is now available to all. Figure 3 shows a screenshot of the Document Delivery/Interlibrary Loan Copyright Policy page.

Figure 3. Image of the Document Delivery/Interlibrary Loan Copyright Policy

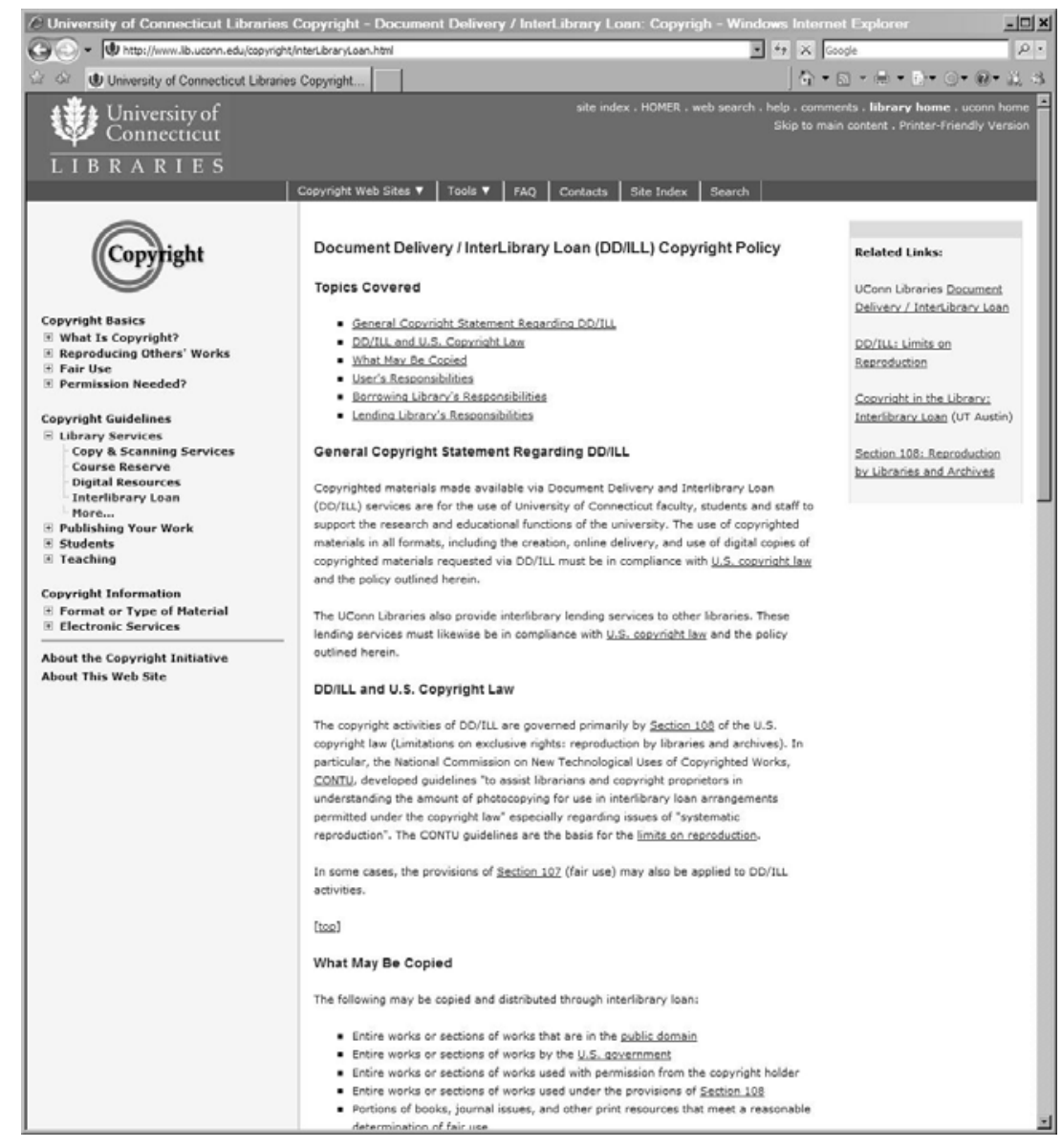

In addition to crafting statements for different library services, the team spent considerable time developing information on "Copyright Basics"-What is copyright? When is something protected by copyright? What is fair use? When do I seek permission? With the basic tools in hand and copyright statements regarding library services, the team assembled topical "index" pages that pointed users to site pages of relevance to faculty and students. For example, the Teaching page pointed instructors to copyright information for course reserve, distance education, and course management software. The team also created cross-reference pages for specific formats-books, images, music, video, microforms, e-text, etc.-and electronic services-digital resources, ePortfolio, institutional repository, course management software, etc. Figure 4 shows a screenshot of the Teaching Index page.

Figure 4. Image of the Teaching Index Page 


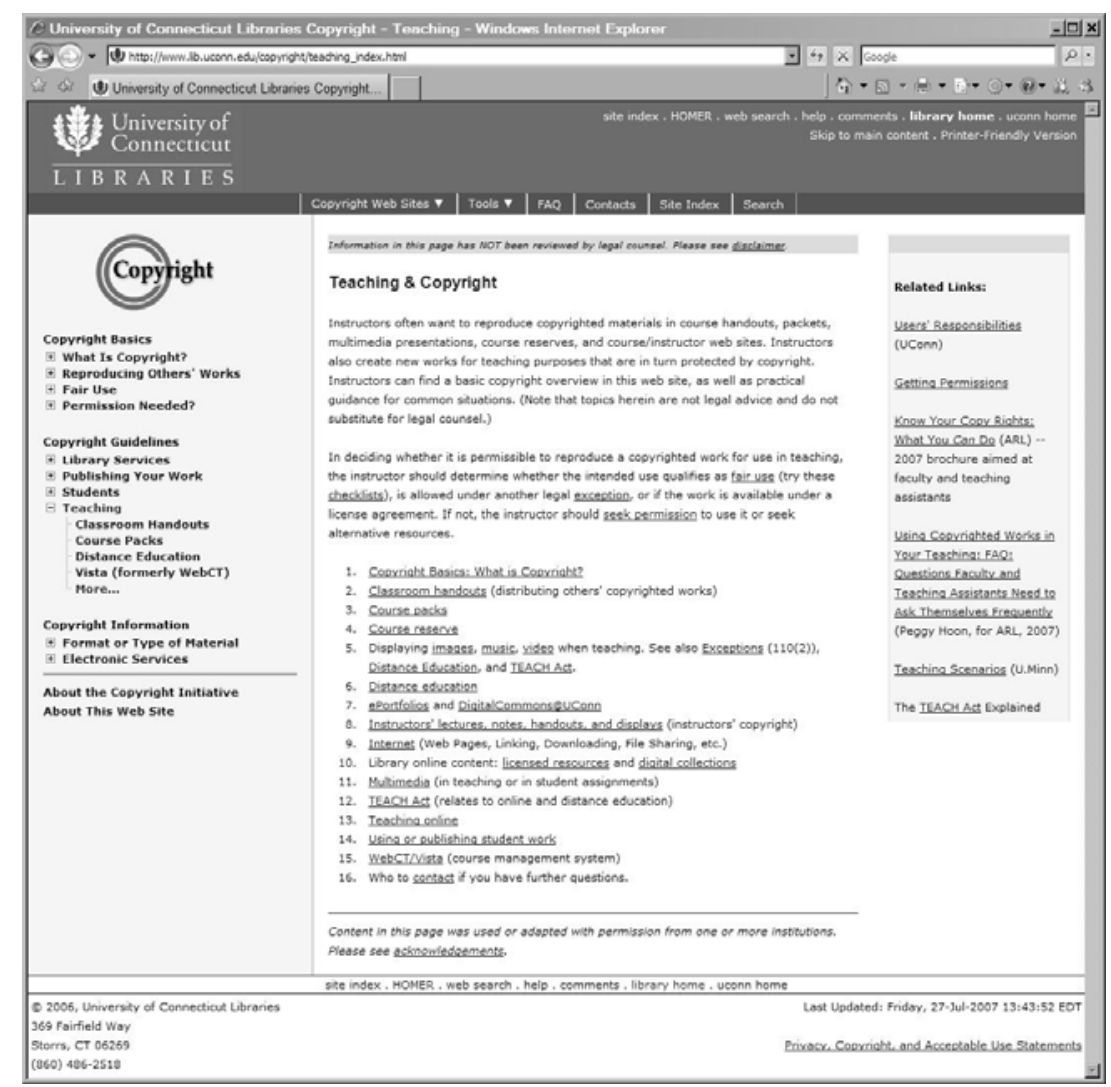

As knowledge of the team's efforts grew among the larger university community, members found themselves fielding questions from far-flung members of that community. These may lead to a future page of exemplars or "scenarios" as object lessons. Examples of some of the more interesting or challenging questions include the following:

- A faculty member asked if she could show her class an episode of a popular talk show that she had taped herself.

- A graduate student wanted to know what his rights and obligations were to the university for software he had written for a class project, but that he thought had potential commercial value.

- A music major wondered if he could upload recordings of university music ensembles in which he had performed to ePortfolio, for use by his advisors, instructors, and potential employers.

- An instructor asked if he needed permission to translate a copyrighted work, or to publish that translation.

- A teaching assistant wanted to show her class the work of former students as examples of how to construct a well-written argument.

- A faculty member wanted to create a string of movie clips to put on electronic course reserve.

In addition to copyright, many of these questions spilled over into the areas of university policy, plagiarism, patents and contract law-topics all well beyond the purview of the copyright team's intended purpose. Still, these matters clearly were related, and users were in need of answers and clarifications. The team found itself in the midst of a larger picture where questions could only be answered using a combination of tools and resources. 


\section{GESTALT-THE WHOLE IS GREATER THAN THE SUM OF ITS PARTS}

The Copyright Project Team is just one of several related and synergistic activities the University of Connecticut Libraries have pursued in recent years in response to internal and external demands and to the Libraries' perceptions of the future of academic libraries. Others include a scholarly communications initiative, an author's addendum and informational brochure, an electronic resource management database (particularly regarding a staff/public interface for license information), and an institutional repository. All of these activities, resources, and tools support one another in an ongoing way and have a cumulative effect on the university environment that is greater than any of them could be as a standalone.

At the recent ACRL conference, members of the project team participated in a poster session (http://www.lib.uconn.edu/copyright/presentations.html) detailing their work over the two years of the team's existence. Presenters found themselves repeatedly asked if the University of Connecticut had these other tools or additional support from the university. Visitors to the session remarked that they had one or another of these resources, but not all, and that through work on the one they were becoming aware that they needed expertise in all of these areas to effectively respond to demands of their users.

Members of the Copyright Project Team have been involved in all of these projects as they have developed, both because of their roles on the copyright team and because they use the tools in their areas of primary responsibility. The copyright team worked with the institutional repository team and university counsel to develop copyright statements for authors placing materials in the repository. One member of the copyright team is also a member of the scholarly communications team, representing copyright interests to that team, and was instrumental in developing an informational brochure for authors about retaining their copyrights. Working in their capacities as selectors and service providers, members of the copyright team gave specifications and offered feedback to electronic-services librarians on an electronic resource management database that provides information to staff on licenses and acceptable uses. The simultaneous coordination and pursuit of all these activities highlighted the relationships between them and added momentum to the Libraries’ overarching agenda of transforming scholarly communications.

\section{NEXT STEPS}

In May 2007, the Copyright Project Team gave its final report to the library's leadership. As a result of the project team's recommendation, a new, permanent copyright team was charged to continue the work begun by the project team. One project team member will stay on permanently, another rotated off, and the third will stay on for one year to allow for transition. Three new members were added, including two from outside the University Libraries. The new team will balance its activities to address a variety of constituents.

First and foremost, the team will continue to develop and refine library copyright policies to reflect changes in the law, university policy, and best practice, and to ensure that affected library staff and users of those library services are informed as to their rights and responsibilities. There will be ongoing consultations with affected parties to maintain stakeholder buy in and awareness of the issues.

Second, and related to policy development and dissemination, the web site remains central to the team's work. The new team will further assess, populate, refine, and promote the library copyright web resource in order to increase its utility, keep up with the fast pace of copyright law developments, and provide guidance for copyright issues at the university. The team especially plans 
reach out to other service and academic units at the university in order to facilitate discussion and bring more links or content under the umbrella of the library's copyright web site.

Third, outreach and training will be an ongoing focus for the new team, both in the library and to selected groups in the university. The team will develop or procure additional educational workshops and materials in order to increase the university community's awareness of rights, responsibilities, and strategies for approaching copyright. Such outreach will continue to foster relationships and partnerships at the university and beyond. It will also help to identify, create, and promote new copyright resources, lead to more pronounced and cohesive articulation of university expectations regarding copyright, and identify further actions to promote discussion in the larger university community.

Finally, the library has proposed the creation of a university-wide copyright committee with a library representative on the committee. The library's copyright team will work to coordinate its efforts with that committee and serve as a resource, with hopes of maximizing the library's investment to-date in its copyright initiative. If the university launches its own copyright web site, the library's site might be retired, or perhaps the university will consider adopting or taking over the library's site for a broader purpose. In either case, the library is positioned to be an integral part of any university-wide initiative.

\section{CONCLUSION}

The past two years have been busy, with the result that the members of the Copyright Project Team have built a valuable and authoritative resource for the university community. The importance of outreach to library staff and university stakeholders cannot be overstated. Public events, such as forums, open meetings, and advertised rollouts of a new web site or service are important milestones that raise awareness and keep stakeholders engaged. Throughout the process, the library has established itself as a leader on copyright issues for the university.

The new copyright team has an opportunity to build on the library's recent successes. Persistent news stories about copyright and intellectual-property battles and the frequency of visits to the University of Connecticut Libraries copyright web site illustrate that there is, and will continue to be, interest in and need for ongoing engagement.

\section{NOTES}

1. The University of Connecticut Libraries, "Strategic Plan 2005-2010," The University of Connecticut Libraries, http://www.lib.uconn.edu/about/administration/strategic/plan2010.doc.

2. The following institutions generously permitted the University of Connecticut Libraries to draw from content and design of their copyright sites: Brown University; Purdue University; Syracuse University; the University of California, Los Angeles; the University of Minnesota; and Washington State University. 


\section{BIBLIOGRAPHY}

All web sites were accessed on 30 May 2007 unless otherwise specified.

\section{Getting Started}

Association of American Universities. Campus Copyright Rights and Responsibilities: A Basic Guide to Policy Considerations. n.p.: Association of American Universities, 2005. http://aaupnet.org/aboutup/issues/Campus Copyright.pdf.

Association of Research Libraries. Know Your Copy Rights: Using Copyrighted Works in Academic Settings. Washington DC: Association of Research Libraries, [2007]. http://www.knowyourcopyrights.org/.

Crews, Kenneth D. et al. Copyright Law for Librarians and Educators: Creative Strategies and Practical Solutions. $2 \mathrm{~d}$ ed. Chicago: American Library Association, 2006.

Lipinski, Tomas A. The Complete Copyright Liability Handbook for Librarians and Educators. New York: NealSchuman, 2006.

U.S. Copyright Office. Copyright. http://www.copyright.gov/.

\section{Model Copyright Web Sites in Higher Education}

Brown University. Copyright and Fair Use. http://www.brown.edu/Administration/Copyright/index.html.

Hoon, Peggy E. Tutorial Series: Copyright Ownership, Copyright Use, Plagiarism, [and] Licensing Guidelines. Raleigh, NC: Scholarly Communication Center of the NCSU Libraries, 2003. http://www.lib.ncsu.edu/scc/tutorial/.

North Carolina State University. Scholarly Communication Center. http://www.lib.ncsu.edu/scc/main.html. With Peggy E. Hoon, J.D., Scholarly Communication Librarian and Special Assistant to the Provost for Copyright Administration, and Annis Barbee, M.A., Scholarly Communication and Information Specialist.

Purdue University. University Copyright Office. http://www.lib.purdue.edu/uco/index.html.

Stanford University Libraries. Copyright \& Fair Use. http://fairuse.stanford.edu/.

Syracuse University Library. Copyright. http://library.syr.edu/copyright/.

UCLA Library. UCLA Copyright Policy. http://www2.library.ucla.edu/copyright/index.cfm.

University of Connecticut Libraries. Copyright. http://www.lib.uconn.edu/copyright/.

University of Minnesota Libraries. Copyright Information \& Education. http://www.lib.umn.edu/copyright/.

University of Texas at Austin. The Copyright Crash Course. http://www.utsystem.edu/ogc/Intellectualproperty/cprtindx.htm. With Georgia K. Harper, J.D., Scholarly Communications Advisor, University Libraries.

Washington State University, University Publishing. Copyright. http://publishing.wsu.edu/copyright/.

\section{Useful Tools or Hot Topics}

Association of Research Libraries. Copyright \& Intellectual Property Policies: Orphan Works. http://www.arl.org/pp/ppcopyright/orphan/index.shtml.

Bailey, Charles W., Jr. Open Access Bibliography. Washington DC: Association of Research Libraries, 2005. http://info.lib.uh.edu/cwb/oab.pdf.

Copyright Clearance Center. Copyright.com. http://www.copyright.com/.

“Copyright Decision Map.” In Copyright Information \& Education at the University of Minnesota Libraries. http://www.lib.umn.edu/copyright/map.phtml.

Creative Commons. http://creativecommons.org/.

Hirtle, Peter B. “Copyright Term and the Public Domain in the United States.” In Copyright Information Center at Cornell University. http://www.copyright.cornell.edu/training/Hirtle_Public_Domain.htm.

“Section 108 Study Group.” In the Library of Congress. http://www.loc.gov/section108/.

SHERPA/RoMEO. "Publisher Copyright Policies \& Self-archiving.” In SHERPA. http://www.sherpa.ac.uk/romeo.php.

SPARC. "Author Rights: Using the SPARC Author Addendum to Secure Your Rights as the Author of a Journal Article.” In SPARC: Scholarly Publishing and Academic Resources Coalition. http://www.arl.org/sparc/author/addendum.html.

“TEACH Act Toolkit: An Online Resource for Understanding Copyright and Distance Education.” In Scholarly Communication Center at North Carolina State University (NCSU). http://www.lib.ncsu.edu/scc/legislative/teachkit/. 